$01 / 7$

RFP-2657

August 20, 1977
RFP-2657

August 20, 1977

\title{
EVALUATION OF ANION EXCHANGE RESINS \\ FOR PROCESSING PLUTONIUM-NEPTUNIUM RESIDUES
}

Chemistry Research and Development

James D. Navratil

Chemical Research Group

Robert G. Leebl

Special Recovery Group

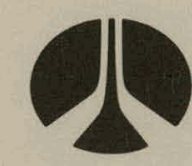

Rockwell International

Atomics International Division

Rocky Flats Plant

P.O. Box 464

Golden, Colorado 80401

U.S. ENERGY RESEARCH AND DEVELOPMENT ADMINISTRATION

CONTRACT EY-76-C-04-3533 


\section{DISCLAIMER}

This report was prepared as an account of work sponsored by an agency of the United States Government. Neither the United States Government nor any agency Thereof, nor any of their employees, makes any warranty, express or implied, or assumes any legal liability or responsibility for the accuracy, completeness, or usefulness of any information, apparatus, product, or process disclosed, or represents that its use would not infringe privately owned rights. Reference herein to any specific commercial product, process, or service by trade name, trademark, manufacturer, or otherwise does not necessarily constitute or imply its endorsement, recommendation, or favoring by the United States Government or any agency thereof. The views and opinions of authors expressed herein do not necessarily state or reflect those of the United States Government or any agency thereof. 


\section{DISCLAIMER}

Portions of this document may be illegible in electronic image products. Images are produced from the best available original document. 


\section{LEGAL NOTICE}

This report was prepared as an account of work sponsored by the United States Government. Neither the United States nor the Energy Research and Development Administration, nor any of their employees, nor any of their contractors, subcontractors, or their employees, makes any warranty, expressed or implied, or assumes any legal liability or responsibility for the accuracy, completeness or usefulness of any information, apparatus, product or process disclosed, or represents that its use would not infringe privately owned rights.

Printed in the United States of America

Available from the

National Technical Information Service

IJ.S. Department of Commerce

Springfield, Virginia 22161

Price: Printed Copy $\$ 4.50$ Microfiche $\$ 3.00$

Price Is Subject to Change Without Notice 


\section{EVALUATION OF ANION EXCHANGE RESINS}

\section{FOR PROCESSING PLUTONIUM-NEPTUNIUM RESIDUES}

Chemistry Research and Development

James D. Navratil

Chemical Research Group

Robert G. Leebl

Special Recovery Group

\section{SUBJECT DESCRIPTORS}

Ion Exchange Neptunium

Plutonium

Actinides

Materials Recovery

Separation Processes

ROCKWELL INTERNATIONAL ATOMICS INTERNATIONAL DIVISION ROCKY FLATS PLANT P. O. BOX 464 GOLDEN, COLORADO 80401

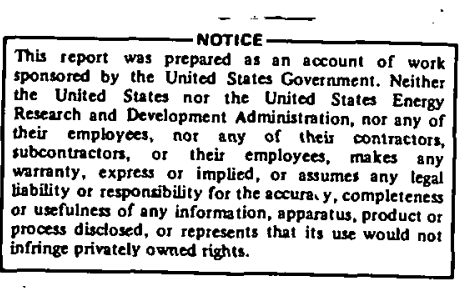

This report was prepared as an account of work
sponsored by the United States Government. Neither the United States nor the United States Energy Research and Development Administmition, nor any of

Prepared under Contract EY.78-C043533

for the

Albuquerque Operations Office

U. S. Energy Research and Dovelopmoit Administration 
RFP-2657 


\section{CONTENTS}

Abstract . . . . . . . . . . . . . 1

Introduction . . . . . . . . . . . 1

Experimental Procedure . . . . . . . . . . . . . 1

Materials . . . . . . . . . . . . 1

Equipment and Procedure :. . . ...... 2

Analysis................ 2

Results and Discussion............ 2

Evaluation of Ion Exchange Resins . . . . 2

Demonstration of the Recovery Process . . . 3

Conclusions ... . . . . . . . . . . . . . . 4

References................. 4

Tables................. 5

Figures ................ . . 8

Appendix I . . . . . . . . . 9 
RFP-2657 


\section{ACKNOWLEDGMENTS}

The authors wish to thank A. H. Miyashita; G. M. Dancer, and J. A. Battaglino for experimental assistance. Appreciation also is extended to $F$. J. Miner and E. Vejvoda for their helpful suggestions, and to the Analytical Laboratories, especlaily R. C. Nelson and R. A. Nixon, for the analyses. 
RFP-2657 


\section{EVALUATION OF ANION EXCHANGE RESINS}

FOR PROCESSING PLUTONIUM-NEPTUNIUM RESIDUES

James D. Navratil and Robert G. Leebl

\section{ABSTRACT}

An anion exchange process was developed to process miscellaneous residues of plutonium plus 0.5 weight percent neptunium to allow prompt return of the plutonium to a plutonium recovery process. Several macroreticular anion $R$ exchange resins were compared to Dowex $1-\mathrm{X} 4$ for the process. Uowex 1-X4 showed the best performance for the plutonium (III)-neptunium(IV) separation.

\section{INTRODUCTION}

A process was needed to recover plutonium from miscellaneous plutonium-neptunium (Pu-Np) residues at Rocky Flats. The plutonium-neptunium residues contained 0.5 weight percent (wt \%) neptunium. The residues were generated from Lawrence Livermore Laboratory-Nevada Test Site events, where the neptunium was used as a radiochemical diagnostic tracer.

An ion exchange process was evaluated to process the residues. Macroreticular strong-base and weak-base anion exchange resins were compared to gel-type Dowex 1-X4 resin for the separation process. This comparison was made because of reported advantages of the weak-base macroreticular resins over gel-type (microreticular) resins for neptunium purification. These advantages include improved thorium decontamination, sharper neptunium elution band, and fivefold lower resin cost. ${ }^{1}$ Higher actinide loading and faster elution were reported for strong-base macroreticular resins. ${ }^{2}$

\section{EXPERIMENTAL PROCEDURE}

Materials

Ferrous sulfamate $\left[\mathrm{Fe}\left(\mathrm{SO}_{3} \mathrm{NH}_{2}\right)_{2}\right]$ was supplied as a 3 M solution from the Shepherd Chemical Company.* . All other chemicals were reagent grade and were used without further purification.

The mixed actinide solutions were prepared by dissolving mixed oxides in $12.5 \mathrm{M}$ $\mathrm{HNO}_{3}$ (nitric acid) -0.1M HF (hydrofiuoric acid). After dissolution, the solutions were filtered, and a stoichiometric amount of aluminum nitrate $\left[\mathrm{Al}\left(\mathrm{NO}_{3}\right)_{3}\right]$ was added to complex the fluoride ion. Dilution of the stock mixed-actinide solutions was usually made with 0.35 M $\mathrm{HNO}_{3}$.

Weak-base Amberlite $(R$ IRA-93 and strongbase Amberlite IRA-900 macroreticular ion-exchange resins were obtained from. Rohm and Haas in the chloride form. Dowex $\mathbb{B}_{\text {MSA-1, a strong-base macro- }}$ reticular resin manufactured by Dow Chemical, U.S.A., also was supplied in the chloride form. All macroreticular resins were 20-50 mesh beads.

Prior to use, all resins except Dowex 1-X4 were re-screened and converted from

\footnotetext{
*Shepherd Chemical Company, 4900 Beech Street, Cincinnati, Ohio.

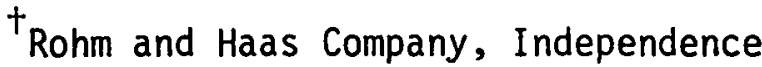
Mall West, Philadelphia, Pennsylvania.
} 
the chloride to the nitrate form with $7 \mathrm{M} \mathrm{HNO}_{3}$. Dowex 1-X4 gel resin (macroreticular, 50-80 mesh beads) was supplied in the nitrate form. The resins were checked by microscope for broken or cracked beads prior to use.

Wash solutions for the ion exchange experiments consisted of $7 \mathrm{M} \mathrm{HNO} \mathrm{HN}_{3}-0.2 \mathrm{M}$ $\mathrm{Fe}\left(\mathrm{SO}_{3} \mathrm{NH}_{2}\right)_{2}$ or. $5 \mathrm{M} \mathrm{HNO} \mathrm{H}_{3}-0.6 \overline{\mathrm{M} \mathrm{Al}}\left(\mathrm{NO}_{3}\right)_{3}$ $0.2 \mathrm{M} \mathrm{Fe}\left(\mathrm{SO}_{3} \mathrm{NH}_{2}\right)_{2}$.

Equipment and Prucedure

Several ion exchange resins were compared for actinide separations on laboratoryscale columns. The resin bed dimensions were 1.7- $\mathrm{cm}$ diameter, $20-\mathrm{cm}$ length for Runs $B$ to $E$ and $1.0-\mathrm{cm}$ diameter, $15-\mathrm{cm}$ length for Runs $A$ and $F$. The feed being investigated was loaded simultaneously onto a column of each of the four different conditioned resins at a flow rate of approximately $2 \mathrm{ml} \cdot \mathrm{min}^{-1} \cdot \mathrm{cm}^{-2}$. After loading, the resins were washed with wash solution and then eluted with $0.35 \mathrm{M} \mathrm{HNO}_{3}$. Samples of the eftluent, wash, and eluate streams were taken periodically and analyzed.

The large-scale anion exchange scheme involved loading neptunium(IV) from a plutonium-neptunium feed solution onto a $15-\mathrm{cm}$ diameter by $76-\mathrm{cm}-\mathrm{high}$ column of Dowex 1-X4 from a $5 \mathrm{M} \mathrm{HNO}_{3}-0.66 \mathrm{M} \mathrm{Al}\left(\mathrm{NO}_{3}\right)_{3}-$ $0.2 \mathrm{M} \mathrm{Fe}\left(\mathrm{SO}_{3} \mathrm{NH}_{2}\right)_{2}$ feed. The plutonium that sorbed on the ion exchange resin was removed from the resin by extended washing with a $5 \mathrm{M} \mathrm{HNO}_{3}-0.66 \mathrm{M} \mathrm{AT}\left(\mathrm{NO}_{3}\right)_{3}-0.2 \mathrm{M}$ $\mathrm{Fe}\left(\mathrm{SO}_{3} \mathrm{NH}_{2}\right)_{2}$ solution. The neptunium was eluted with $0.35 \mathrm{M} \mathrm{HNO}_{3}$.

\section{Analysis}

Plutonium concentration was determined radiometrically except for $\geq 10$ grams per litre of plutonium solutions, which were analyzed by $X$-ray fluorescence. The neptunium concentration was determined by radiometric pulse-height analysis. This determination followed separation of the plutonium by an ion exchange or solvent extraction procedure.

The iron(II) normality in ferrous sulfamate was determined by a volumetric ceric sulfate titration. Nitric acid concentrations were determined by acidbase titrations.

\section{RESULTS AND DISCUSSION}

Evaluation of Anion Exchange Resins

Macroreticular strong-base (Dowex MSA-1 and Amberlite IRA-900) and weak-base (Amberlite IRA-93) anion exchange resins were compared to a gel-type resin (Dowex 1-X4) for plutonium-neptunium separations. Laboratory-scale runs involved the loading of neptunium from a plutonium(III)neptunium(IV) feed solution onto four resins simultaneously from either $7 \mathrm{M}$ $\mathrm{HNO}_{3}$ or $5 \mathrm{M} \mathrm{HNO}_{3}-0.66 \mathrm{M} \mathrm{Al}\left(\mathrm{NO}_{3}\right)_{3}$ feed solutions containing $0.2 \mathrm{M}\left[\mathrm{Fe}\left(\mathrm{SO}_{3} \mathrm{NH}_{2}\right)_{2}\right]$.

Ferrous sulfamate was uscd by itself as the reducing agent; it reduces $\mathrm{Pu}(\mathrm{VI})$ and $\mathrm{Pu}$ (IV) to $\mathrm{Pu}$ (III), and it reduces $N p(V I)$ and $N p(V)$ to $N p(I V)$. The use of hydrazine to help stabilize the reducing conditions are not permitted in the process because of hydrazine's redctivity. IJse of $5 \mathrm{M} \mathrm{HNO}_{3}-0.66 \mathrm{M} \mathrm{Al}\left(\mathrm{NO}_{3}\right)_{3}-0.2 \mathrm{M}$ $\mathrm{Fe}\left(\mathrm{SO}_{3} \mathrm{NH}_{2}\right)_{2}$ instead of $7 \mathrm{M} \mathrm{HNO}_{3}-0.2 \mathrm{M}$ $\mathrm{Fe}\left(\mathrm{SO}_{3} \mathrm{NH}_{2}\right)_{2}$ feed media provided the most stable separation conditions. The lower acidity prevented significant oxidation $[<1 \% \mathrm{Pu}(\mathrm{IV})]$ of plutonium within one day, and the increased nitrate concentration from $\mathrm{Al}\left(\mathrm{NO}_{3}\right)_{3}$ maintained maximum sorption of neptunium(IV). Each of the lab-scale experiments was completed within several hours. 
The resins were compared for neptunium breakthrough, elution, and plutonium(III) washing behavior. Table 1 shows the relative resin order of increasing neptunium concentration in the ion column effluent (ICE) for the resins tested. When high plutonium concentrations were present in the feed (Run $A$ ), the neptunium concentration was less in the ICE for the macroreticular resins; however, for lower plutonium feed concentrations, the neptunium levels were lowest for the gel resin (Dowex 1-X4). Apparently this is due somewhat to the loading of plutonium(IV), present in equilibrium with $\mathrm{Pu}$ (III), in addition to neptunium(IV). Increasing plutonium breakthrough capacities for macroreticular resins was observed with an increase in plutonium feed concentrations. ${ }^{3}$ Neptunium breakthrough was $<10 \%$ (i.e., neptunium concentration in the ICE divided by neptunium concentration in feed $=0.1)$ for all experiments except Run A (see Appendix I).

For the resins tested, Table 2 shows the relative resin order of increasing neptunium concentration in the wash solutions. (Appendix I shows the actual concentrations.) Since the removal of plutonium(III) requires large volumes of wash solution, the concentration of neptunium in the wash effluent is an important factor in selection of a resin. Results show that the level of neptunium in the wash effluent was lowest for Dowex 1-X4 and very high for the weak-base macroreticular resin (Amberlite IRA-93).

Figure 1 shows the washing profile for plutonium(III) on the anion exchange resins. The difference between the two runs ( $A$ and $F$ ) can be attributed to the different size columns (bulk column volume of 11.8 versus $45.4 \mathrm{ml}$ ), and the different wash solutions. Amberlite
IRA-93 gave superior performance over the other resins in relation to plutonium(III) removal by washing. Dowex MSA-1 gave the poorest washing behavior, but it was not much worse than Dowex 1-X4. The results of three other runs $(B-D)$ gave the same washing order as shown in Figure 1.

The neptunium elution data on the resins are shown in Table 3 . Complete elution data were obtained on only four of the experiments. The majority of the results shows that the neptunium elution order on the resins was Amberlite IRA-900 > Amberlite IRA-93 > Dowex MSA-1 > Dowex 1-X4 (slowest). As with the plutonium (III) washing results, there are no great differences between the elution behavior of the resins.

In summary, based on the lowest neptunium concentration observed in the ICE and wash, Dowex 1-X4 was superior to the macroreticular resins. This advantage of the gel resin outweighed the better washing and elution characteristics of the macroreticular resins, especially since washing and elution differences were not large. Other batches of some of the resins could give variations in performance. This has been observed by other investigators. ${ }^{4}$ The possibility of this variation and its effect should be evaluated prior to largescale application of any separation process.

\section{Demonstration of the Recovery Process}

Three successful demonstration runs of the ion exchange process were made on large-scale equipment. The neptunium(IV) was loaded onto a 15-cm-diameter by 76-cm-high column of Dowex 1-X4 (50-80 mesh) from a $5 \mathrm{M} \mathrm{HNO}_{3}-0.66 \mathrm{M} \mathrm{AI}\left(\mathrm{NO}_{3}\right)_{3}-$ $0.2 \mathrm{M} \mathrm{Fe}\left(\mathrm{SO}_{3} \mathrm{NH}_{2} \bar{T}_{2}\right.$ feed. Most of the non- 
sorbable plutonium(III) was allowed to pass through the column in the ICE. The remainder of the plutonium was removed from the resin by extended washing with a $5 \mathrm{M} \mathrm{HNO} \mathrm{H}_{3}-0.66 \mathrm{M} \mathrm{Al}\left(\mathrm{NO}_{3}\right)_{3}-0.2 \mathrm{Me}\left(\mathrm{SO}_{3} \mathrm{NH}_{2}\right)_{2}$ solution.

Plutonium in the resultant ICE and wash stream was adjusted to the tetravalent species with sodium nitrate, and the resulting solution was returned to the waste stream for purification by a second ion exchange process. Additional neptunium decontainillaliun of the plutonium was also achieved during the second ion exchange step. The neptunium loaded on the column during the first ion exchange step was eluted with $0.35 \mathrm{M}$ $\mathrm{HNO}_{3}$ and was either recycled or precipitated with $7 \mathrm{M}$ potassium hydroxide $(\mathrm{KOH})$, calcined, and stored.

Results of the demonstration runs are shown in Table 4. A large amount of plutonium(III) was removed in the ICE of the first run compared to the second run (53 versus 8 percent). A lower concentration of plutonium in the feed in the first run apparently was responsible for this larger amount. Because of equipment problems, both runs had to be terminated before complete plutonium removal could be achieved by washing. Complete washing was accomplished in the third run, and half the plutonium followed the ICE - apparently because of the larger volume of feed processed.

The large volume of feed ( 7 column volumes) processed in the third run apparently caused the increase in neptunium concentration in the ICE and wash. The average neptunium concentration in the combined washes and ICE for the other two runs was approximately 0.3 milligram per litre. This was acceptable for return to the waste stream via plutonium purification by anion exchange technology. During the three runs, 63, 75, and 98 percent of the plutonium in the residues was separated and returned to the waste stream. Neptunium losses to the plutonium were not critical since the objective was prompt recovery of the plutonium. Neptunium and plutonium remaining on the columns were eluted with $0.35 \mathrm{M} \mathrm{HNO}_{3}$ and will be reprocessed in subsequent runs on a routine basis.

\section{CONCLUSIONS}

Several macroreticular anion exchange resins were compared to Dowex 1-X4 (microreticular resin) for processing miscellaneous residues of plutonium and 0.5 wt \% neptunium. Based on the lowest neptunium concentrations observed in the effluents, Dowex $1-X 4$ was superior to the macroreticular resins. This advantage of the microreticular resin outweighed the better washing and elution characteristics of the macroreticular resins, especially since washing and elution differences were small.

Three successful demonstration runs of the ion exchange process were made on large scale equipment. The developed process effectively separated plutonium (III) and neptunium(IV) from the mixed actinide residues, which allowed prompt return of the plutonium to a plutonium recovery process.

\section{REFERENCES}

1. W. W. Schulz. Application of Amberlite XE-270 Resin to Purification of Neptunium. ARH-SA-149. At7antic Richfield Hanford Company, Richland, Washington. May 1973.

2. G. H. Thompson and G. A. Burney. Processing of ${ }^{238} \mathrm{Pu}$ and ${ }^{237} \mathrm{~Np}$ with 
Macroporous Anion Exchange Resin. DP-1333. E. I: du Pont de Nemours \& Company, Savannah River Plant, Aiken, South Carolina. November 1973.

3. J. D. Navrati1. Rockwell International, Rocky Flats Plant. January 1976. Unpublished results.
4. G. H. Thompson. Rockwell International, Rocky Flats Plant. November 1976. Private communication.

\section{TABLES}

TABLE 1. Relative Resin Order of Increasing Neptunium Concentration in the Ion Column Effluent (ICE)

\section{Feed}

\begin{tabular}{cc}
\hline $\mathrm{Pu}$ & $\mathrm{Np}$ \\
$(\mathrm{g} / \mathrm{T})$ & $(\mathrm{g} / \mathrm{I})$
\end{tabular}

Relative Resin Order

Run

8.3

0.16 for. Np in ICE

A

7.6

3.7

$900<93<1<1-\times 4$

B

4.3

2.9

$900<1-X 4<1<93$

D

4.8

0.92

$1-X 4<900<1<93$

E $\quad 3.3$

0.66

$1-\times 4<900<1<93$

$\mathrm{F}$

1.5

0.039

$1-\times 4<93$

$1-X 4<1<900<93$

Feed media was $5 \mathrm{M} \mathrm{HNO}_{3}-0.66 \mathrm{M} \mathrm{Al}\left(\mathrm{NO}_{3}\right)_{3}-0.2 \mathrm{M}$ $\mathrm{Fe}\left(\mathrm{SO}_{3} \mathrm{NH}_{2}\right)_{2}$ except for Runs $\mathrm{B}$ and $\mathrm{D}$, which were $7 \underline{\mathrm{M}} \mathrm{HNO}_{3}-0.2 \underline{\mathrm{Me}}\left(\mathrm{SO}_{3} \mathrm{NH}_{2}\right)_{2}$ feed media. 
TABLE 2. Relative Resin Order of Increasing Neptunium Concentration in. Wash Solutions

\begin{tabular}{|c|c|c|}
\hline Run & $\begin{array}{c}\text { Wash } \\
\text { Solution }\end{array}$ & $\begin{array}{l}\text { Relative Resin Order } \\
\text { for } N p \text { in the Wash }\end{array}$ \\
\hline A & I I & $1-\times 4<1<900<93$ \\
\hline B & I & $1-\times 4<900<1$ \\
\hline C & I I & $1-\times 4<900<1<93$ \\
\hline D & I & $1-x 4<1 \simeq 900<93$ \\
\hline$E$ & I I & $1-\times 4<93$ \\
\hline $\mathrm{F}$ & I I & $1-x 4<900<1<93$ \\
\hline
\end{tabular}

a. Wash solutions:

$$
\begin{aligned}
& \mathrm{I}-7 \underline{\mathrm{M}} \mathrm{HNO}_{3}+0.2 \underline{\mathrm{M}} \mathrm{Fe}\left(\mathrm{SO}_{3} \mathrm{NH}_{2}\right)_{2} \\
& \mathrm{II}-5 \underline{\mathrm{M}} \mathrm{HNO}_{3}+0.66 \underline{\mathrm{MAI}}\left(\mathrm{NO}_{3}\right)_{3}+0.2 \underline{\mathrm{M} \mathrm{Fe}}\left(\mathrm{SO}_{3} \mathrm{NH}_{2}\right)_{2}
\end{aligned}
$$

TABLE 3. Neptunium Elution of the Resins

$$
\begin{aligned}
& \text { Column Volumes of } 0.35 \mathrm{M} \mathrm{HNO}_{3} \text { Required } \\
& \text { To Elute } 90 \% \text { of the Neptunium }
\end{aligned}
$$

\begin{tabular}{lcccc}
\cline { 2 - 4 } Description & $\begin{array}{c}\text { Dowex } \\
1-X 4\end{array}$ & $\begin{array}{c}\text { Amberlite } \\
\text { IRA-900 }\end{array}$ & $\begin{array}{c}\text { Dowex } \\
\text { MSA-1 }\end{array}$ & $\begin{array}{c}\text { Amberlite } \\
\text { IRA-93 }\end{array}$ \\
\cline { 2 - 3 } & 7 & 5 & 6 & 5 \\
B-Eluate & 7 & 4 & 6 & 5 \\
D-Eluate & 7 & 4 & 6 & 5 \\
E-Eluate & 6 & - & - & 5
\end{tabular}


TABLE 4. Results of Process Demonstration Runs

\begin{tabular}{|c|c|c|c|}
\hline & $\begin{array}{c}\text { Cumulative } \\
\text { Column } \\
\text { Volumes } \\
\end{array}$ & $\begin{array}{l}\text { Plutonium } \\
C / C_{0}\end{array}$ & $\begin{array}{l}\text { Neptunium } \\
(\mathrm{mg} / \mathrm{l})\end{array}$ \\
\hline $\begin{array}{l}\operatorname{ICE}^{C} \text { (Run 1) } \\
\text { Wash } \\
\vdots\end{array}$ & $\begin{array}{l}2.2 \\
4.1 \\
6: 4\end{array}$ & $\begin{array}{l}0.53 \\
0.59 \\
0.63\end{array}$ & $\begin{array}{l}0.28 \\
0.48 \\
0.15\end{array}$ \\
\hline $\begin{array}{l}\text { ICE } \\
\text { Wash }\end{array}$ & $\begin{array}{r}2.3 \\
4.5 \\
6 \quad 6.5 \\
8.5 \\
10.3 \\
12.5\end{array}$ & $\begin{array}{l}0.08 \\
0.16 \\
0.22 \\
0.31 \\
0.55 \\
0.75\end{array}$ & $\begin{array}{l}0.31 \\
0.81 \\
0.14 \\
0.28 \\
0.16 \\
0.26\end{array}$ \\
\hline$I_{C E}^{e}(\operatorname{Run} 3)$ & $\begin{array}{r}7 \\
15 \\
17\end{array}$ & $\begin{array}{l}0.47 \\
0.84 \\
0.98\end{array}$ & $\begin{array}{l}0.73 \\
0.90 \\
0.41\end{array}$ \\
\hline
\end{tabular}

a. Column volume $=13.9$ litres; flow rate $=10$ litres per hour.

b. $\quad C / C=$ concentration of plutonium in ion column effiuent (ICE) or wash streams divided by plutonium concentration in feed.

c. ICE using feed containing 2.35 grams per litre of plutonium and 33.9 milligrams per litre of neptunium.

d. ICE using feed containing 7.25 grams per litre of plutonium and 61.9 milligrams per litre of neptunium.

e. ICE using feed containing 6.94 grams per litre of plutonium and 34.6 milligrams per litre of neptunium. 
FIGURE 1. Plutonium(III) Washing Profile on Several Resins

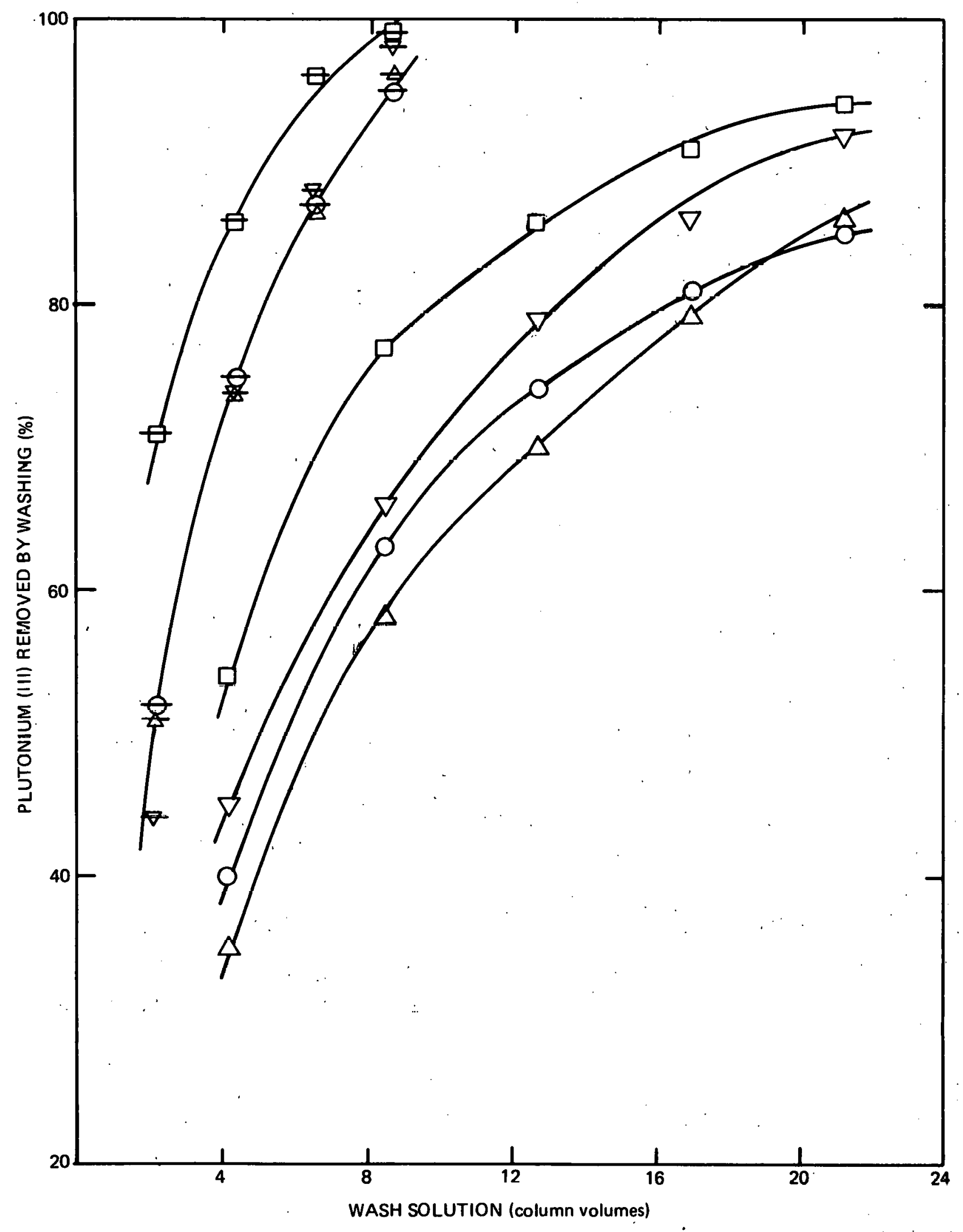




\section{APPENDIX I}

Neptunium Concentration and Neptunium-to-Plitonium Ratios

in Ion Column Effluent and Wash

\begin{tabular}{|c|c|c|c|c|c|c|c|c|c|c|c|}
\hline \multirow[b]{2}{*}{$\begin{array}{c}\text { Descrip- } \\
\text { tion } \\
\end{array}$} & \multicolumn{3}{|c|}{ Fed to Columns } & \multicolumn{2}{|c|}{ Dowex 1-X4 } & \multicolumn{2}{|c|}{$\begin{array}{l}\text { Amberlite } \\
\text { IRA-900 }\end{array}$} & \multicolumn{2}{|c|}{ Dowex MSA-1 } & \multicolumn{2}{|c|}{$\begin{array}{c}\text { Amberlite } \\
\text { IRA-93 }\end{array}$} \\
\hline & $\begin{array}{c}\mathrm{Pu} \\
(\mathrm{mg} / \mathrm{ml})^{\mathrm{a}}\end{array}$ & ${\stackrel{\mathrm{Np}}{(\mathrm{mg} / \mathrm{ml})^{\mathrm{a}}}}^{\mathrm{c}}$ & Wash $^{b}$ & $\begin{array}{c}\mathrm{Np} \\
(\mathrm{mg} / \mathrm{l})\end{array}$ & $\begin{array}{l}\mathrm{Np} / \mathrm{Pu} \\
\text { (ppm) }\end{array}$ & $\begin{array}{c}\mathrm{Np} \\
(\mathrm{mg} / 1) \\
\end{array}$ & $\begin{array}{l}\mathrm{Np} / \mathrm{Pu} \\
(\mathrm{Opm})\end{array}$ & $\begin{array}{c}\mathrm{Np} \\
(\mathrm{mg} / \mathrm{T})\end{array}$ & $\begin{array}{l}\mathrm{Np} / \mathrm{Pu} \\
(\mathrm{ppm})\end{array}$ & $\begin{array}{c}\mathrm{Np} \\
(\mathrm{mg} / 1) \\
\end{array}$ & $\begin{array}{l}\mathrm{Np} / \mathrm{Pu} \\
(\mathrm{ppm})\end{array}$ \\
\hline $\begin{array}{l}\text { A-ICE } \\
\text { A-ICE } \\
\text { A-ICE } \\
\text { A-WASH } \\
\text { A-WASH } \\
\text { A-WASH }\end{array}$ & $\begin{array}{l}26 \\
62 \\
97 \\
-- \\
-- \\
--\end{array}$ & $\begin{array}{l}0.5 \\
1.2 \\
1.9 \\
--- \\
--- \\
---\end{array}$ & $\begin{array}{l}--- \\
--- \\
--- \\
2.1 \\
11 \\
19\end{array}$ & $\begin{array}{c}76 \\
110 \\
99 \\
4.1 \\
0.58 \\
---\end{array}$ & $\begin{array}{r}11,000 \\
15,000 \\
13,000 \\
1,800 \\
.950 \\
---\end{array}$ & $\begin{array}{c}24 \\
62 \\
62 \\
16 \\
4.0 \\
---\end{array}$ & $\begin{array}{r}6,800 \\
11,000 \\
11,000 \\
3,200 \\
2.700\end{array}$ & $\begin{array}{l}72 \\
97 \\
94 \\
7.9 \\
3.0 \\
2.2\end{array}$ & $\begin{array}{r}12,000 \\
15,000 \\
15,000 \\
2,800 \\
3,000 \\
4,100\end{array}$ & $\begin{array}{l}43 \\
95 \\
86 \\
14 \\
3.8 \\
0.28\end{array}$ & $\begin{array}{r}8,700 \\
14,000 \\
12,000 \\
3,300 \\
5,200 \\
1,100\end{array}$ \\
\hline $\begin{array}{l}\text { B-ICE } \\
\text { B-WASH }\end{array}$ & $\begin{array}{r}8 \\
--\end{array}$ & $\begin{array}{l}4 \\
--\end{array}$ &.-- & $\begin{array}{l}0.11 \\
0.06\end{array}$ & $\begin{array}{l}20 \\
40\end{array}$ & $\begin{array}{l}0.02 \\
0.10\end{array}$ & $\begin{array}{r}300 \\
70\end{array}$ & $\begin{array}{l}0.13 \\
0.36\end{array}$ & $\begin{array}{l}200 \\
300\end{array}$ & $\begin{array}{l}0.30 \\
0.78\end{array}$ & $\begin{array}{l}500 \\
400\end{array}$ \\
\hline $\begin{array}{l}\text { C-ICE } \\
\text { C-WASH }\end{array}$ & $\begin{array}{r}5 \\
--\end{array}$ & 3 & $\begin{array}{l}--- \\
6.6\end{array}$ & $\begin{array}{l}0.02 \\
0.02\end{array}$ & $\begin{array}{r}500 \\
70\end{array}$ & $\begin{array}{l}0.03 \\
0.22\end{array}$ & $\begin{array}{l}300 \\
500\end{array}$ & $\begin{array}{l}0.26 \\
7.6\end{array}$ & $\begin{array}{r}200 \\
18,000\end{array}$ & $\begin{array}{l}0.44 \\
13\end{array}$ & $\begin{array}{r}200 \\
14,000\end{array}$ \\
\hline $\begin{array}{l}\text { D-ICE } \\
\text { D-WASH }\end{array}$ & $\begin{array}{l}21 \\
--\end{array}$ & $\begin{array}{l}4 \\
---\end{array}$ & --- & $\begin{array}{r}<0.53 \\
0.20\end{array}$ & $\begin{array}{l}50 \\
60\end{array}$ & $\begin{array}{l}1.6 \\
4.4\end{array}$ & $\begin{array}{r}400 \\
1,400\end{array}$ & $\begin{array}{l}2.3 \\
3.7\end{array}$ & $\begin{array}{r}910 \\
1,200\end{array}$ & $\begin{array}{l}5.8 \\
7.4\end{array}$ & $\begin{array}{l}1,200 \\
2,500\end{array}$ \\
\hline $\begin{array}{l}\text { E-ICE } \\
\text { E-WASH }\end{array}$ & $\begin{array}{l}15 \\
--\end{array}$ & $\begin{array}{l}3 \\
---\end{array}$ & --- & $\begin{array}{l}0.03 \\
0.75\end{array}$ & $\begin{array}{r}30 \\
850\end{array}$ & $--\cdot$ & -- & $\cdots$ & -- & 31.0 & $\begin{array}{r}1,300 \\
36,000\end{array}$ \\
\hline $\begin{array}{l}\text { F-ICE } \\
\text { F-ICE } \\
\text { F-WASH } \\
\text { F-WASH }\end{array}$ & $\begin{array}{l}23 \\
54 \\
-- \\
--\end{array}$ & $\begin{array}{l}0.6 \\
1.4 \\
--- \\
---\end{array}$ & $\begin{array}{l}--- \\
--- \\
6.4 \\
15\end{array}$ & $\begin{array}{c}<0.44 \\
2.1 \\
0.30 \\
0.11\end{array}$ & $\begin{array}{r}<600 \\
2,800 \\
420 \\
240\end{array}$ & $\begin{array}{l}1.3 \\
1.7 \\
0.52 \\
---\end{array}$ & $\begin{array}{r}1,900 \\
2,100 \\
.930 \\
-.-\end{array}$ & $\begin{array}{l}1.0 \\
1.3 \\
0.87 \\
1.6\end{array}$ & $\begin{array}{l}2,000 \\
1,800 \\
1,800 \\
6,300\end{array}$ & $\begin{array}{l}5.0 \\
8.2 \\
2.5 \\
1.5\end{array}$ & $\begin{array}{r}6,000 \\
8,000 \\
11,000 \\
31,000\end{array}$ \\
\hline
\end{tabular}

a. Milligrams of plutonium or neptunium fed to columns per millilitre of resin.

b. Bulk column volumes of wash solution fed to columns. 
RFP-2657 